\title{
Effective Project Team Organization in Project Management Practices
}

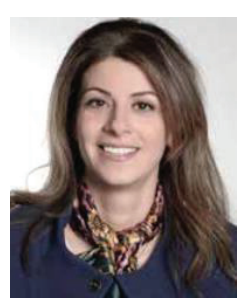

\author{
Dr. Karen Boujaoude Khoury \\ Notre Dame University; Faculty of Arts, Architecture and Design \\ Department of Architecture \\ kaboujaoudeh@ndu.edu.lb
}

\begin{abstract}
The study focuses on architecture practice and the tensions that arise within the profession as a result of a variety of systems of performance. Particularly it gives attention to the weak collaboration between the design-construction phases that are composed of several sequential steps called the project process. The problem arises from a lack of organization and the need for project management in architecture as a result of the increase in interrelated tasks assigned for the architect to deal with and the complexity of architecture projects in hand. These organized jobs require a number of expertise working together who might not have same interests to share common goals. The study covers the importance and significance of project management in the construction industry and analyzes the problems in managing architecture projects raising potential conflicts in communication and stressing on weak collaboration in the architecture engineering construction industry (AEC industry). The research highlights the importance of project team organization in the success of project delivery and determines the means and tools of successful communication for that purpose. The elements facilitating team communication are listed as effective variables essential for the success of project delivery.
\end{abstract}

Keywords: Project management, construction, team organization, building

\section{Proje Yönetimi Uygulamalarında Etkili Proje Ekibi Organizasyonu}

Öz: Çalışma, mimarlık pratiği ve çeşitli performans sistemlerinin sonucu olarak meslek içinde ortaya çıkan gerginliklere odaklanmaktadır. Özellikle proje süreci olarak adlandırılan birkaç ardışık adımlardan oluşan tasarım-inşaat aşamaları arasındaki zayıf işbirliğine dikkat verir. Sorun, mimarın başa çıkabilmek için verdiği birbiriyle bă̆lantılı görevlerin artması ve mimari projelerin eldeki karmaşıklı̆̆ sonucunda organizasyon eksikliği ve mimaride proje yönetimine duyulan ihtiyaçtan kaynaklanmaktadır. Bu organize işler, ortak hedefleri paylaşmak için aynı ilgi alanlarına sahip olmayan birlikte çalışan bir dizi uzmanlık gerektirir.

Anahtar kelimeler: Proje yönetimi, yapım, takım organizasyonu, bina.

\section{INTRODUCTION}

Construction projects and their outcomes seriously influence the contemporary culture; therefore, the significance of a well-functioning construction industry is an essential element [1]. In various, several countries; the construction industry has, nevertheless, concerned analysis for unsuccessful outcomes such as time and cost overruns, low productivity, poor quality, and insufficient customer satisfaction [2]. Practitioners, researchers, and the social order at large have consequently, called for a change in interrelations, behavior, and dealings in order to boost the probability for project success and improve results [3]. The customer is proposed to act as a change mediator in such a transformation [4].

Doi Num : 10.17932/IAU.ARCH.2015.017/arch_v05i2001 


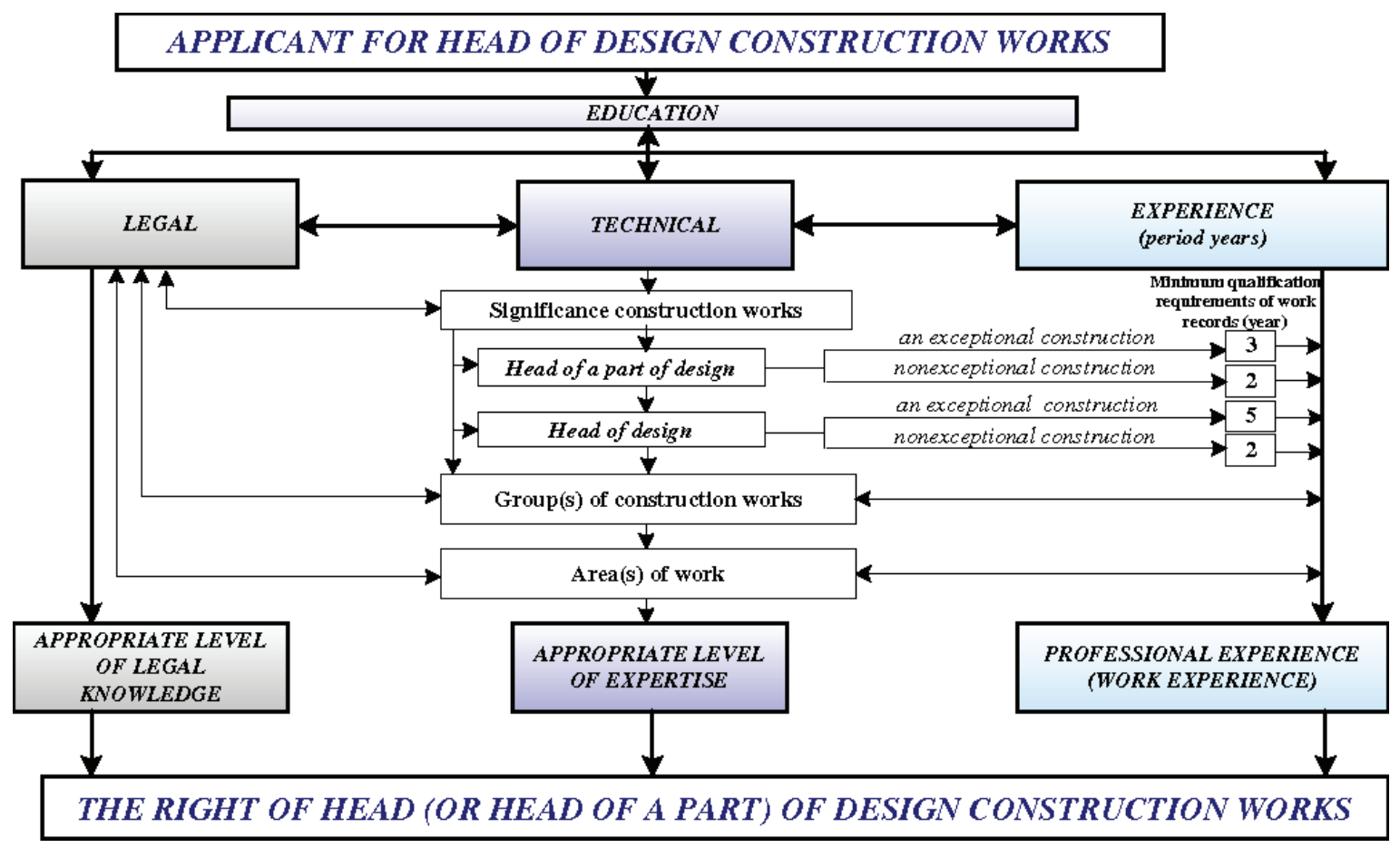

Figure 1. Applicant for head of design construction works [5]

Even though many attempts have been made within the last two decades to develop and apply new technologies in order to improve quality and costs, no major change have affected the construction industry over the same period of time. The AEC industry has been opposing all the business changes for productivity improvement as in other industries. The present condition of division needs to be changed. Change is required to generate a setting that enhances innovation, clarifies communication, and assimilates the design, manufacturing and construction processes. While every architectural product is fairly becoming the subject of change, all the products are tagged with various titles, periods and concepts under the influence of the transformation process. This situation puts the matter of consumption on the agenda and sets up a world in which constructed models are gradually consumed and considerations of quality become lost under the title of "diversification" [6]. 


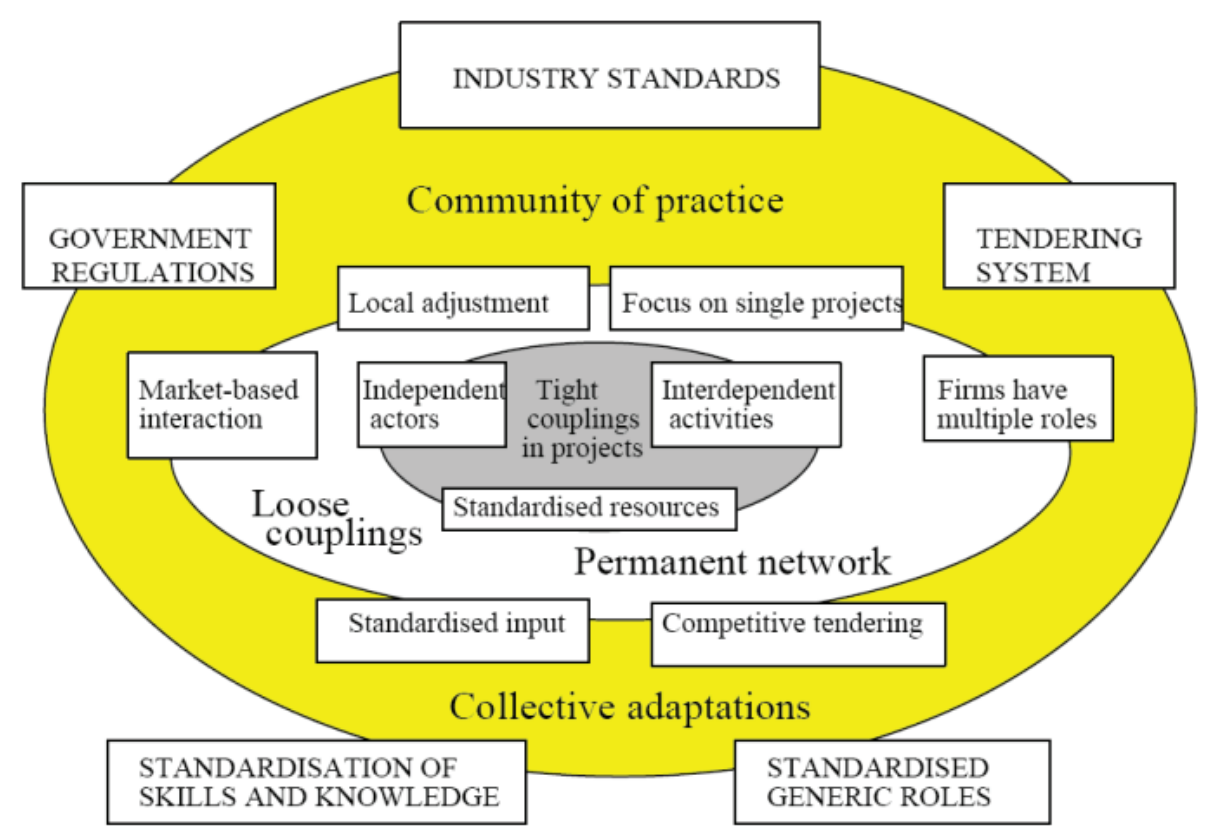

Figure 2. The pattern of couplings [7]

The construction industry is known for its slow pace of change and its multiple divisions in process [7]. Any architecture project should follow a definite process from design to construction. It is a multi-stage process, which includes design conception, approval of design by the client, construction plans, specialized tasks approved, and finally construction or implementation on site. It is considered a multi-organization process, which involves the client, designer, contractor, supplier, consultant, etc. Since the sequence of the tasks in the construction project requests the completion of one task in order to start the other, then data related was considered the basic concept upon which the exchange of information in such projects should be studied [8].

\subsection{Research Objective}

Project management in architecture is the organization of activities performed in construction organizations that mainly deal with "planning, executing, coordinating, and controlling projects," resulting in building new structures [9]. Unluckily, due to poor value of management practices, several construction projects do not meet their targets $[10,11]$. Consequently, the incentive for this research is the call for project success improvement in the construction region. Particularly, this work focuses the effect of different organizational structures on communication within a construction project $[12,13,14]$.

The significance of project management in the construction sector has quickly increased in the last few decades. Accordingly, project managers, planners, and estimators ought to struggle to constantly advance their project management qualifications. Inefficient productivity, such as time delays and cost overruns, are not uncommon in construction projects [15], and the reasons behind these troubles have concerned the awareness of construction practitioners and researchers. For instance, Mansfield et al. (1994) [16] acknowledged the four vital factors behind time delays and cost overruns as finance and payment problems, poor deal management, modifications in site conditions, and scarcity of materials. Moreover, the study by Kaming et al. (1997) [17] reveals the major factors affecting time delays are design changes, poor effort productivity, insufficient planning, and resources deficiency, whereas cost overruns are normally 
attributable to objects price increases, inexact material evaluation, and project complexity. Similarly, (Malik et al. 2007) [18] recommended that time delays and cost overruns occur principally as a consequence of payment difficulties.

Project management is defined as the organization of a set of orders and commands in adequate detail to tell the project team precisely what must be done, once it must be accomplished and what resources to make use of in order to generate the deliverables of the project productively and effectively [19].

The project manager, who must make certain that the project, is carried out appropriately and to the complete fulfillment of all relevant stakeholders. Major compensations of proper project planning are to:

- $\quad$ get rid of or reduce uncertainty;

- develop efficiency of the process;

- $\quad$ get hold of a better understanding of project objectives; and

- Grant a basis for monitoring and controlling effort [20].

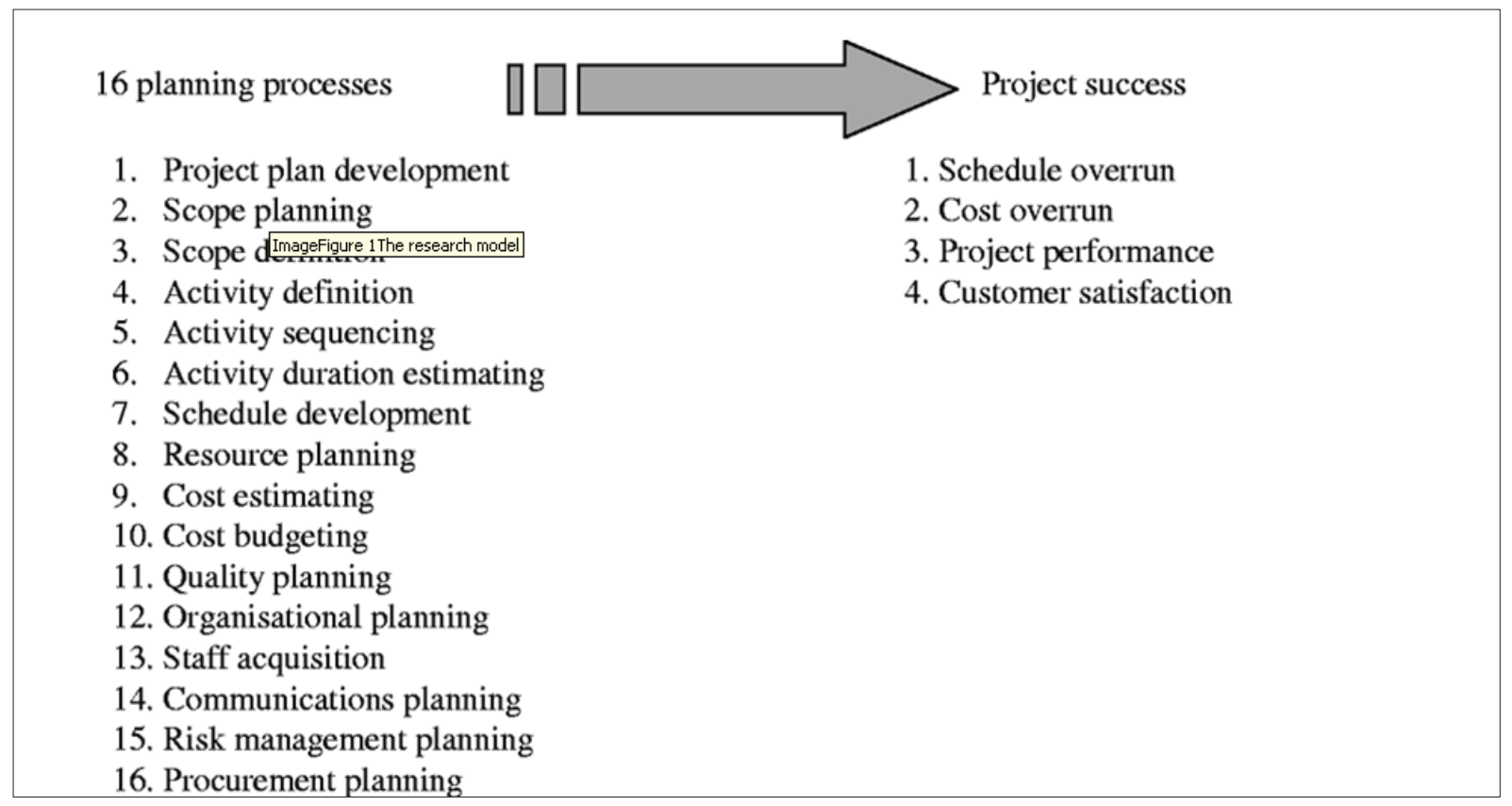

Figure 3. The Planning Phases and Process [21]

The main product of the planning phase is the project plan as achieved by the project team during the planning phase of the project. The project plan includes the following elements: general idea, project objectives, universal approach, contractual features, calendars, possessions, personnel, risk-management plan, and assessment methods [19]. (Sequentially to extend a project plan, more than a few managerial processes ought to be executed. Probable lists of planning processes are established in dissimilar sources. For instance, Russell and Taylor (2003) [22] recognized seven planning processes, which consist of defining project objectives, identifying activities, establishing preference relationships, manufacturing time estimates, acquiring project completion time, comparing project timetable objectives, and shaping resource requirements to assemble objectives. Kerzner (2006) [20] spot nine major mechanisms of the planning phase as intention, plan, calendar, financial plan, estimate, organization, strategy, process and typical. 


\section{LITERATURE REVIEW}

Little attention is given to the design team who organizes the process of functions from the beginning till the end of project. The arrangement of the design team structure is therefore a basic step in the process of the process management. As noted by Chiu, "Team organization is one of the major tasks in design collaboration, because it can affect design communication and performance." Where he focuses in his study, An Organizational View of Design Communication in Design Collaboration, on the importance of organization on the whole process of the project and its quality [23].

Referring to general managerial journals, Jack Welch suggested reducing the boundaries that create a closure over one's work and separates the tasks of one project, all this without leading to a chaotic form or structure. This reflects the need of smooth communication in the organization structure between the parties in the practice.

Most construction projects drift towards increased complications, vagueness, and time pressure in construction projects, which has rendered long-established procurement measures and outdated governance forms $[3,24]$. Therefore, a transformation towards improved flexibility, organization, data exchange, and collaboration is usually essential for the demanding construction project characteristics [24]. Since the usual competitive procurement actions create many obstacles in today's demanding project contexts [24].

The next section will cover the theories on the value of organizational structures in the success of project management and delivers a variety of project delivery systems that are analyzed and examined in each of the case studies of this research.

Professional coordination such as joint ventures reveals the technical advantage and cost reduction to complete the assigned tasks, but within this evolution, the architect finds himself a partner of many in the same project which reduces his value in his profession and limits his job. The architect struggles between several tasks in architecture practice; trying to manage between design, engineering solutions, interior decorations and construction and implementation. Communication conditions between several people is summarized in the figure below:

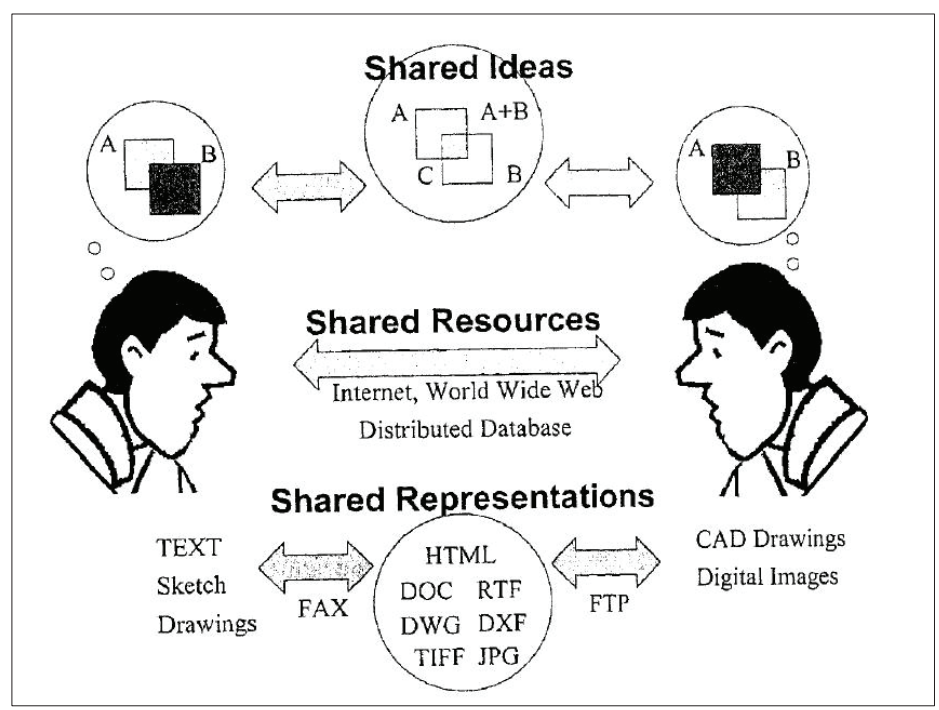

Figure 4. Communication between participants [25]. 
A chain of communication theories have been recognized by researchers of organizational behavior and management science. The active process of human communication results in the effect of one person on the other intentionally or involuntarily through different aspects of resources and materials [25].

The way a project team is structured can play a major role in how it functions. Different styles of team will have different characteristics. Within a team you will find a mixture of different people with different assignments - but that does not necessarily require a hierarchy. The best team cultures develop where team members recognize that everyone else also has important value to contribute [25].

\section{Collaborative Teams}

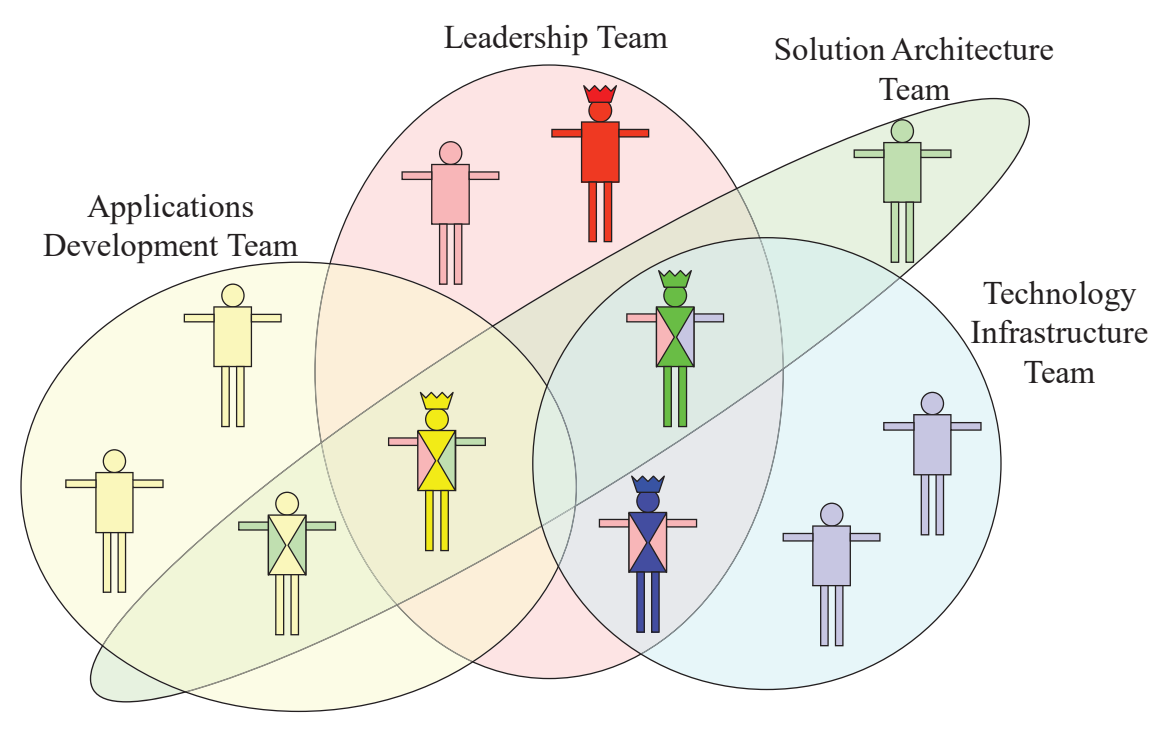

Figure 5. Collaborative teams [26]

The figure extracted from a study on collaborative teams reveals a diagonal selection of members belonging to a variety of positions which enriches the communication process and makes it more successful.

A fine, well-organized design process requires many features, but they are all based on four concepts: recognizing the tasks and their principal uniqueness; previous programming, along with the work schedule; scheduling resources, in terms of equipment and resources, and re-estimating [20]. Robinson et al observes that the preparation of building works, both public and private, is a complex task, and its main intention involves "supplying drawings for the various work fronts so that it is possible to understand, clearly and precisely, exactly what is to be built." [27].

Cole 2000 highlights the value of this practice, since it allows problems and defects to be defeated and put right by anticipating them. Cox et al 2006, in the meantime, points out that the preparation of works is intended to facilitate a number of factors, "like quality, safety, deadlines, cost and environment, and so it is a complex process, with all these factors being interconnected" [28]. 
Importance of team organization in the design of buildings is attracting the attention of many researchers due to the increase in the complexity of technical and organizational structure of any construction project [24].

Harmonizing team communication is: a team effort and it would appear that a bottom-up approach to the management of team communication is required to improve effectiveness. Developing a common understanding of effective communication in the team and using the most appropriate means for the purpose is a fundamental aspect of team performance. Team members have to experience the practical and effective use of new communication technologies in their daily work" as understood by Eriksson and Westerberg in 2010.

The success of a team-based organization is related to the management systems and structures which must be supportive of teamwork, together with employee selection method; reimbursement and incentive programs; performance evaluation procedures; teaching programs, mainly with reference to team-skills; information organizations to meet the requirements of empowered teams; and scheduling and resource allocation systems [24].

The effect of team organization on communication in project management, which is exposed in the literature review, is tested in all case studies to indicate facilitators and ensure successful project delivery.

\section{THE RESEARCH METHODOLOGY}

The article refers to a study of 7 different case studies chosen from the top 10 architecture firms in Lebanon. They encounter $85 \%$ of the Lebanese construction market. They follow different organization models and cover a variety of business construction projects. The case studies include design and construction participants from the same or separate organizations or even geographically distant firms in order to define the project's needs and goals. The cases also summarize the relationship between the architect and the different project delivery systems and his/her job according to other participants. The principles extracted are studied and summarized to be used in the structure of productive communication teams in project management.

Table 1. Summary of case studies

\begin{tabular}{|l|l|l|l|l|l|}
\hline Project name & Scale & Duration & Type & Location & $\begin{array}{l}\text { Construction } \\
\text { Cost }\end{array}$ \\
\hline Beirut National Library & Medium & 3 years & Governmental & Beirut & 7 million dollars \\
\hline Credit Libanais & Medium & 4 years & Private & Beirut & 7 million dollars \\
\hline Clemenceau 306 & Medium & 4 years & Private & Beirut & 9 million dollars \\
\hline $\begin{array}{l}\text { A Public project in Beirut } \\
\text { City District }\end{array}$ & Large & 6 years & Public & Beirut & 50 million dollars \\
\hline $\begin{array}{l}\text { Urban Project in Jeddah- } \\
\text { KSA }\end{array}$ & Large & 6 years & Public/Urban & Jeddah & 70 million dollars \\
\hline $\begin{array}{l}\text { Emergency Unit } \\
\text { Rehabilitation and Extension }\end{array}$ & Medium & 3 years & Institutional & Beirut & 2 million dollars \\
\hline $\begin{array}{l}\text { Residential and commercial } \\
\text { project in Beirut }\end{array}$ & Large & 5 years & $\begin{array}{l}\text { Private/ } \\
\text { Public }\end{array}$ & Beirut & 10 million dollars \\
\hline
\end{tabular}




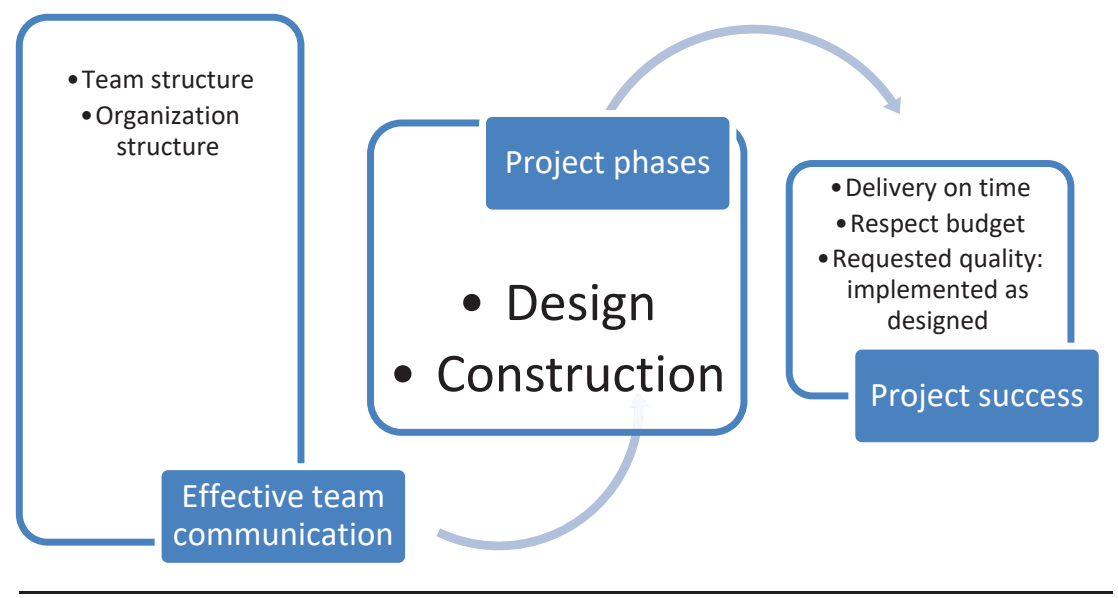

The study examines different project delivery systems and their effect on the project's success through effective team communication.

Different design process models in the selected case studies reveal the importance of team structure and communication links between participants.

With respect to Chan, and based on the study of communication structure in several case studies, the more complex the project is, the more organization becomes hierarchal. Therefore, it is essential to break the whole group into smaller ones that makes communication easy and more efficient in terms of information flow. He points out both, the mesh and star network in the organization structure that are used between or within groups. The level of communication is determined by the size and nature of project [25].
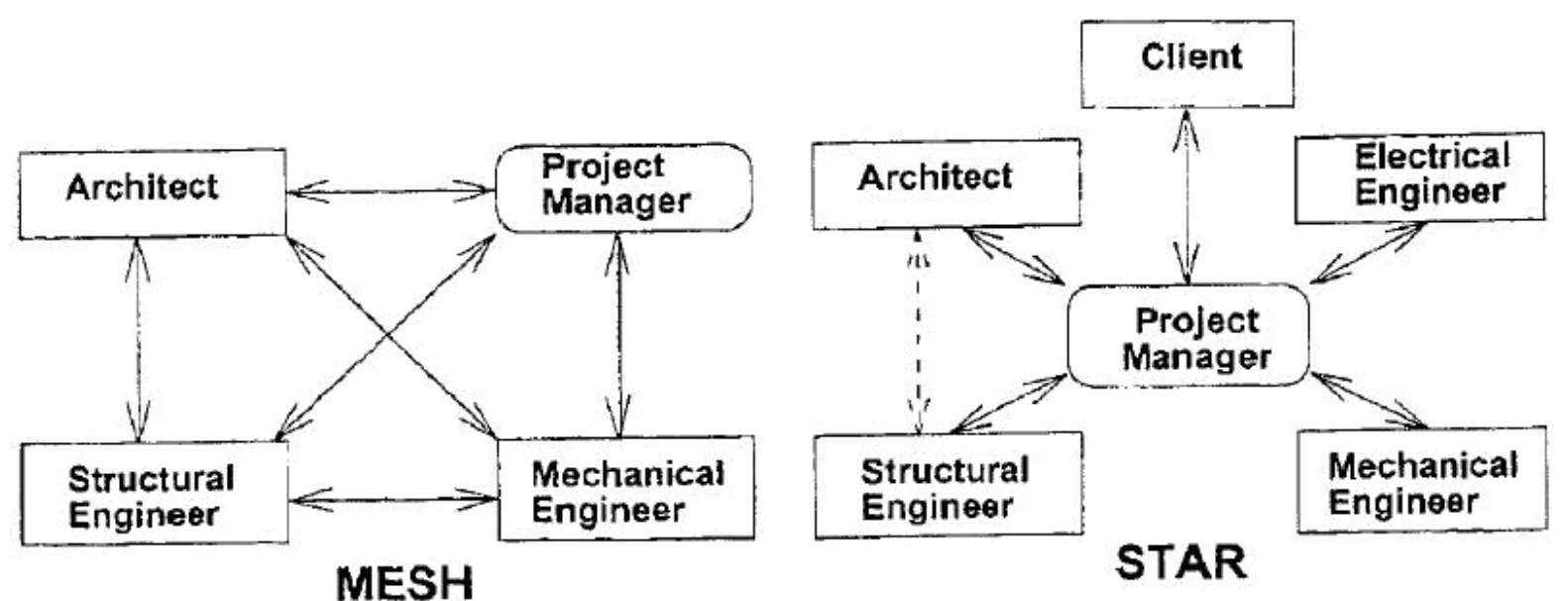

Figure 6. Organization Structure as Centralized and Decentralized [25:33]. 
Based on this study, architecture firms are considered dynamic dealing with several entities that makes their organization closer to a decentralized system. This stresses upon the need for a well-organized structure in architecture firms that strengthens communication between all involved members.

"The notion in complexity hypothesis reverses the usual views of project management achieved over the last 50 years and move from a Cartesian/Newtonian paradigm to a more "complex" view [29]. Although there is no one definite definition of "complexity theory" as its main beliefs have enthused many academics and practitioners in the field of managerial studies, business management [30], and recently disaster management and communication [31]. Normally, complexity theory is very much concerned with: the study of the dynamics of complex adaptive systems which are non-linear, have self-organizing attributes and emergent properties" [18].

"The casual, relaxed communication networks in oppose to the emergence of a disaster as the new communication structures are constructed between project participants based on the shared information and anxiety. Changes and guidelines driven by the top management are usually doubtful to create preferred effects lacking local individuals' coordination. They frequently exchange energy with their surroundings through the self-organizing and emergent property of the complex systems; they even permit impulsive and natural manners and generate new patterns. This allows them to bear in a state that is far-from-equilibrium, "on the edge of chaos" [32], where order and disorder, stability and chaos co-exist." [15].

Kaufman explains the need and importance of communication in the human social life. "In applying complexity theory to communication management in the context of crisis response, the interactive patterns between individuals and organizations that underlying the shifting social aggregations can be better understood" [20].

An increase in the flow of information tends to drive an organization away from stability; at some critical points [33]. A suitable style of management and leadership encouraging communication and association between organizational members is necessary to allow self-organizing of communication" [15].

The team organization structure extracted from the several case studies are summarized as follows:

\section{The Beirut National Library Project}

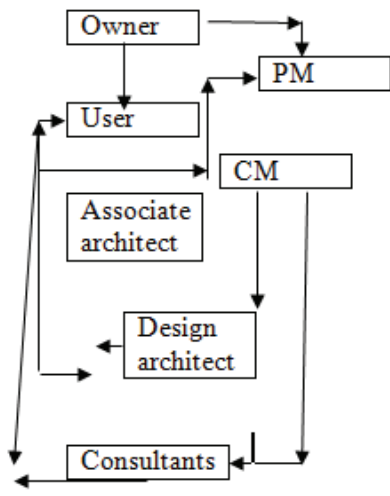

The design architect is legally under the executive, however he has direct communication with the user which made it easy for both to transform the conceptual idea into reality in construction.

The project manager developed a smooth communication system between all the participants which ensured the design quality of the project. 


\section{The Credit Libanais Headquarters}

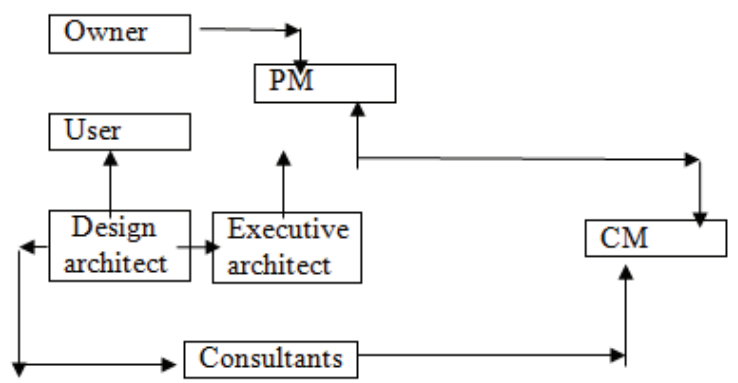

The owner who selected the executive architect caused a tension in the relationship between the design architect and himself. But the role that the executive architect played was important in defining the roles of each participant and drawing a system of interaction which made the collaborative system easy and clear.

\section{The Clemenceau 306}

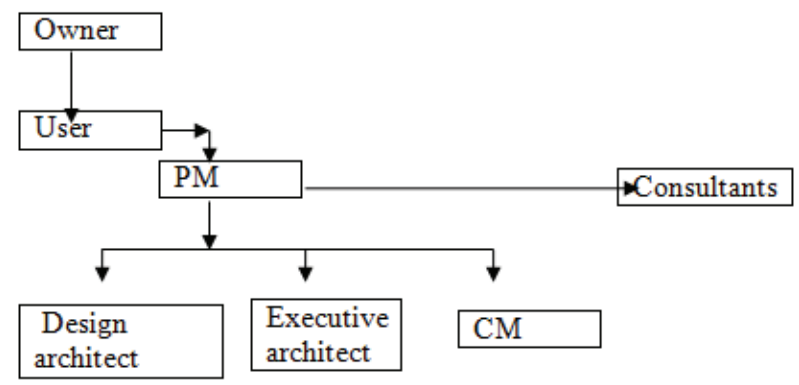

The hierarchal system of work made the communication clear and easy, however elongated the time frame of the project which was saved by increasing the number of participants especially in the execution phase. The project manager who was assigned responsible for the whole project redesigned the structure to follow up the planned outline.

\section{A Public project in Beirut City District}

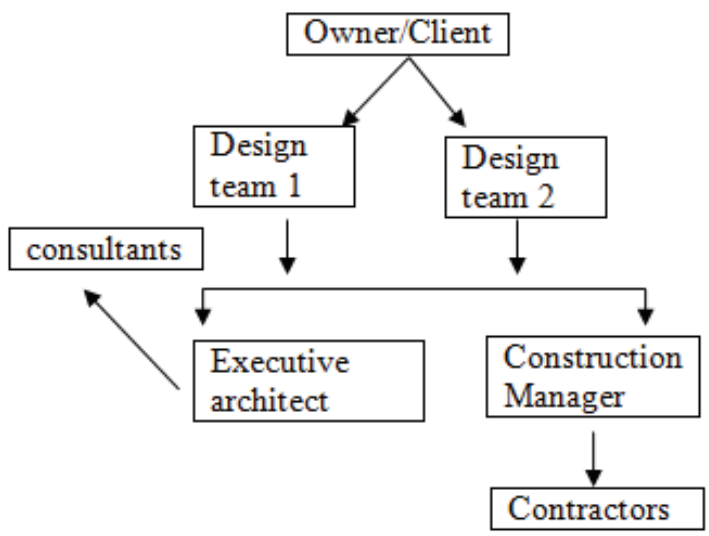

The work had to be accomplished in parallel with another design department assigned by the client. This system of work resulted with a clash on the approval of designed plans which limited the role of the architect to the cad drawings only.Contractors did not have any relation or contact with the design architects or the executive architects. They had to learn new technological innovations in order to understand the designed plans. 


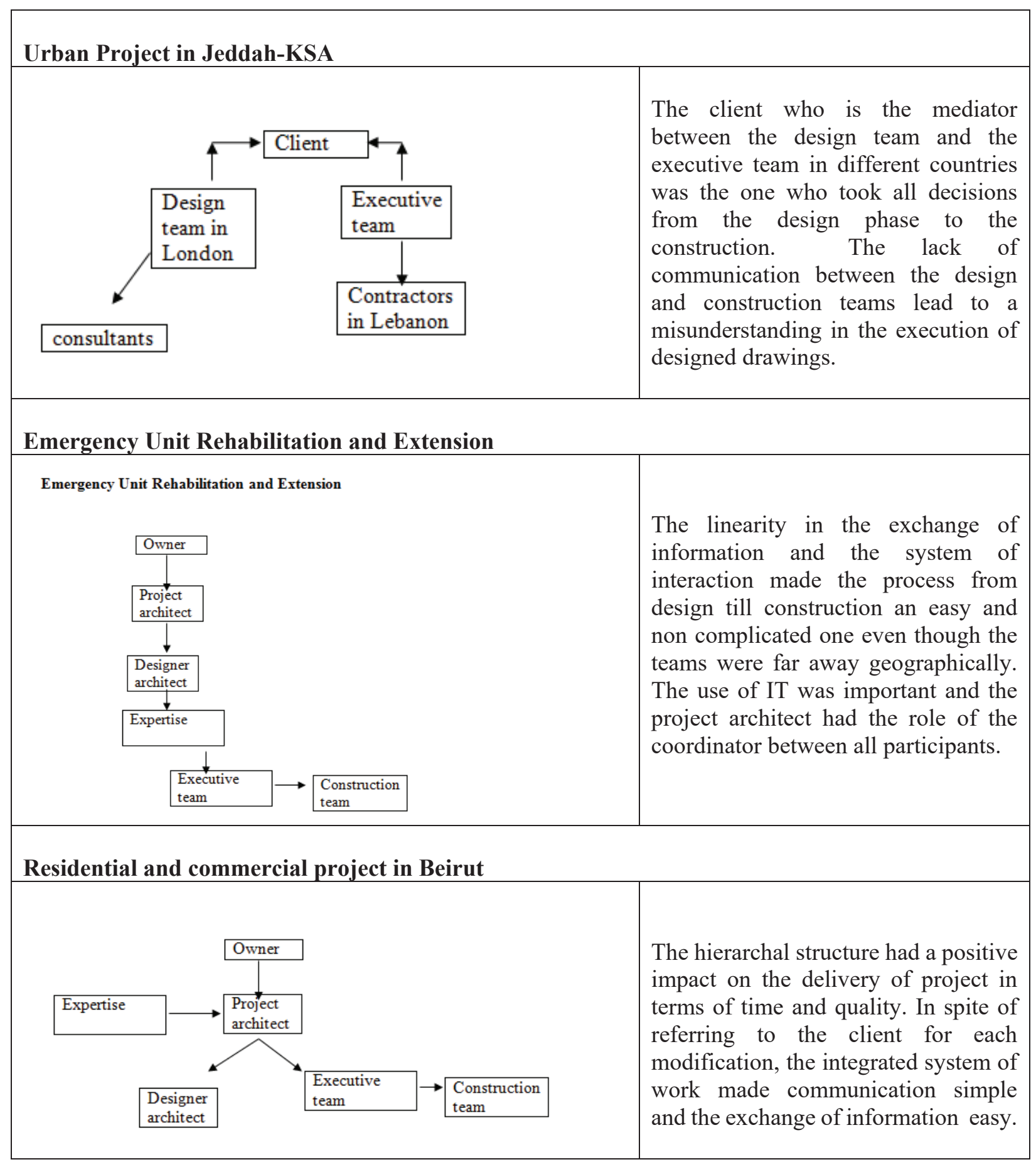


Team communication facilitators are summarized and listed in the table 2:

\begin{tabular}{|c|c|c|c|c|c|c|}
\hline Facilitators & Owner & $\begin{array}{l}\text { Project } \\
\text { manager }\end{array}$ & $\begin{array}{l}\text { Design } \\
\text { Architect }\end{array}$ & $\begin{array}{l}\text { Executive } \\
\text { architect }\end{array}$ & Consultant & $\begin{array}{l}\text { Construction } \\
\text { manager }\end{array}$ \\
\hline \multicolumn{7}{|l|}{ Organizational System } \\
\hline 1 Contact With Client & & & $\mathrm{X}$ & $\mathrm{X}$ & & $\mathrm{X}$ \\
\hline 2 Local Partner & $\mathrm{X}$ & & & & & \\
\hline 3 Originality & $\mathrm{X}$ & & $\mathrm{X}$ & $\mathrm{X}$ & & \\
\hline $\begin{array}{lrc}4 & \text { Ability } & \text { To Work } \\
\text { With New Methods }\end{array}$ & & $\mathrm{X}$ & & $\mathrm{X}$ & $\mathrm{X}$ & $\mathrm{X}$ \\
\hline $\begin{array}{l}5 \text { Leadership/ Clear } \\
\text { Objectives }\end{array}$ & $\mathrm{X}$ & $\mathrm{X}$ & & & & \\
\hline 6 Local Collaborator & & & $\mathrm{X}$ & $\mathrm{X}$ & & \\
\hline 7 Partnering & $\mathrm{X}$ & & & & & \\
\hline 8 Learning & & & & $\mathrm{X}$ & & \\
\hline $\begin{array}{l}9 \text { Participation In The } \\
\text { Design Process }\end{array}$ & $\mathrm{X}$ & $\mathrm{X}$ & & & & \\
\hline $\begin{array}{l}10 \text { Informal } \\
\text { Communication }\end{array}$ & & & $\mathrm{X}$ & $\mathrm{X}$ & & \\
\hline 11 Flexibility & $\mathrm{X}$ & & & & & \\
\hline 12 Lessons Learnt & & & $\mathrm{X}$ & & & \\
\hline 13 Direct Operation & & & $\mathrm{X}$ & $\mathrm{X}$ & & \\
\hline
\end{tabular}

The impact of team structure on the communication linkages has been examined through each proposition:

\section{P1:The impact of team structure on communication links}

Proposition1: The impact of team structure on communication links determined the participant's role in successful communication. This did not vary whether the firm had local or international links. In either cases, the factor had a high impact on affecting the communication links that leads to the success of the architecture project and stresses on the importance of people rather than organizations.

P2: The impact of project delivery system on communication links

Proposition 2: The impact of project delivery system on communication links was delivered by all firms according to the organization of tasks related to each project. The models presented a common structure that enhances communication between participants. This happens to be the hierarchal structure, the most effective one in architecture firms in Lebanon. It focuses on the Importance of people and team structure.

\section{RESULTS (In terms of organization structure and human factor)}

Building the team: organization structure

Teambuilding is significant for the successful achievement of any project. The purpose of the team is to deliver a project that completes on time, is on or below budget, is cost-effective to all team members, with no claims, and consequences in a pleased owner. Challenge, certification battles, doing hazardous actions 
out of spite, and other disturbing actions may result in at least an unpleasant work atmosphere and more likely an unproductive project.

The client plays a guidance role in encouraging and maintaining the team setting. Structuring and preserving the team is in this individual's best interest. Ways of team building start with establishing common goals, accepting and establishing mutual respect between team members.

"Productive teamwork is an essential aspect of professional practice. Architects can improve their ability to work together by employing a set of basic team-building activities that can help architecture teams improve communication, creativity, and performance." [34].

The construction team is frequently considered as including the architect or engineer (design team), owner (client's representative), and freelancer (builder). The design team is composed of architects, engineers and consultants that create the construction plans for the client. The client could be a public or private unit that presents the project necessities and financial support for design and construction. The outworker typically builds an exclusive project in a very aggressive setting. Other members that affect a project team are public involvement and governmental regulators.

\section{The human factor}

These team members allocate the common goal of building a project, but because of contradictory and challenging concern a project may undergo a need of teamwork. These disconnected interests are a result of the broken nature of the industry, developing new team members for every project, and the diverse perspectives or priorities that are common to some degree in all projects.

The construction method is a very viable setting for the client, design team, and contractor. The owner requests the finest value and uppermost quality for their given budget. The design team struggles to accomplish this for the owner and is within the restrictions to activate a successful business. The contractor works in a very competitive industry where revenue margins are low and risk are high. The competitive scenery of these members may cause a crash of the teamwork vital to an extremely successful project. This collapse causes; early information flow, mistrust, too much documentation, costly delays, reduced quality, and eventually affects the cost and timetable of a project.

The need to organize people is therefore a must when involved members increase and communication becomes more complicated. "In integrated project delivery, the architect and contractor work together, often as part of the same integrated firm. As a result, project communication and coordination often run more smoothly than in traditional project delivery, which separates designer and builder. This collaboration has many benefits for design and construction practitioners and their clients." [34].

\section{DISCUSSION}

\section{Teamwork and its success criteria}

Teamwork is known as "cooperative effort by the members of a group or team to achieve a common goal" [35]. The case studies identify successful practices team members that can be used to generate an improved cooperative endeavor between members of the project team or teambuilding in the construction industry. Teambuilding is defined as a procedure planned to develop a project's performance. Enhancing the performance is delivering a project with high quality, within the budget, on time and without any claims or disagreements. 
Teambuilding engages definite tasks that are usually a division of the construction process but are accomplished with the purpose to generate a team. The objectives of these activities are to promote communications, support coordination and cooperation, keep away from possible problems, disputes and maintain high moral.

Teambuilding requests a firm effort on somebody's part; this is usually done by the client delegate or a Construction Manager (CM). The owner's representative or CM naturally has construction contracting knowledge and their background is either from the design professional's or builder's point of view. These participants of the team should make it their assignment and take a management role to generate and foster teambuilding since it is in their and the projects best significance. This management and control cannot work as a top down mandated procedure but should be more of a trainer or even cheerleader helping as the role model and making available tools to promote teambuilding. The manager of the teambuilding hard work should know the strengths of individuals and organizations and use this to help make the team more interconnected and organized.

\section{Defining Team Goals}

The earliest step in teambuilding is to congress the team and organize common and shared project goals. This can be as easy as a preconstruction assembly or as official as a facilitated partnering conference [36]. All the project stakeholders should be there at this kick-off meeting. A team operates professionally when everybody agrees upon shared project goals and objectives. This meeting also provides as a method for the group of actors to get to be acquainted with one another and extend a team "win-win" attitude rather than we/they manners.

Cooperatively the team should describe and agree upon common team and project goals that offer reason, meeting point, and direction. Goals should be precise, considerable, achievable, significant, and timebound. Throughout the recognition of stakeholders' particular goals for the project, common objectives can appear [24].

A straightforward illustration of a team objective is the project schedule. The builder makes a revenue by finishing as soon as possible. The client may call for a competence by a precise date, as seen in case number two, Credit Libanais Headquarters project, where the design team only has a restricted time frame for the construction phase budgeted. A win-win approach is the feature for each of the participant's objectives i.e. builder desires; fast replies to demand for information, owners requests; general coordination and cooperation, and the designer needs; assist with field solutions to problems against redesign.

\section{Building successful Team Communication}

Unsuccessful communication can create excessive stress and pressure between team members, which lowers equally honest and efficiency that can show the way to loss of time and money. Efficient teams work during breakdowns in connections by rising and promoting open and clear communication among its team members. The three key fundamentals to successful project communications are significance, awareness, and happening. Appropriate communication is alert, to the point, and task-oriented. Approachable communication engages the enthusiasm to collect information from others, dynamic listening, and building on thoughts and views from others. Occurrence is recognized communication ways and timely reactions. Postponed upon desired communication within team members can only cause matters to irritate and lead to a collapse of the team and its performance.

Excellent team negotiations rely on how fine team members are capable to communicate with each other. By accepting others and passing on your thoughts you will help breakdown communication obstacles. 
Strategies for practicing open communications are:

- Be enthusiastic to convey yourself and your views completely.

- Stay away from becoming annoyed or annoyed when another person's view varies from yours.

- Be prepared to modify your views as new information becomes accessible.

- Consider win-win by looking for common ground on matters.

- Apply pro-active listening.

Pro-active listening is discovering others ideas to a certain extent than debating their ideas. Bender and Septelka 2000 [37], have proposed five steps in applying pro-active listening:

1. Support the person to communicate their ideas, opinions, and views.

2. Watch and pay attention to what the other person thinks, feels, means and does.

3. Understand what the other said by means of open-ended questions.

4. Accept by paraphrasing and playing back what the other assumed without judgment or problem solving.

5. Interpret what they said and watch and listen, or ask for verification, that you correctly interpreted their ideas, thoughts, and views.

Some barriers to watch out for are:

- Judging a person idea by condemning, name calling, identifying or admiring evaluatively.

- Transferring solutions by arranging, ultimatums, frightening, moralizing, advising, or too much and unsuitable questions.

- Keep away from the other's persons worries by switching, using reasonable opinions, or encouraging.

- "Silent treatment" moving away from calls, delayed reactions, avoiding uncomfortable matters [38].

Frequent team meetings are an efficient communication technique to talk about project matters. All the stakeholders need to be in presence and the gathering needs to be prearranged to be successful. The meeting must include a chosen facilitator that maintains the meeting on time, improves open discussions so that everybody is heard, and reports decisions completed in the meeting. Everybody on the team is full of activity and the majority of meetings can be seized successfully within an hour. The meeting schedule should be sent out previous to the meetings and meeting notes with allocated action items must punctually go after all meetings. In a meeting it is simple to misunderstand what was said and an official recording will permit everyone to interpret and understand the identical interpretations thus saving the project time and money. A way needs to be in place to permit corrections to be completed to the minutes if there is an inconsistency in what was recorded.

Communication among team members has never been so simple and fast. Email, cell phones, the internet, and extranets all permit projects to be organized 24 hours, 7 days a week. Several cautions come with via these innovative technologies that tolerate immediate communications. With the failure of personal contact we mislay the capability to watch and ensure the sender's body verbal communication. Electronic mail can be quickly written and can communicate incorrect purposes when not sufficient time is permitted for the sender or receiver to examine the communications or problem in a complete point of view. Email can be rapidly forwarded to others without the senders' awareness, so make sure what you write down is projected for anyone's eyes. It is significant that you consider first and make sure you are not expressive over the issue and it is suggested to make clear any issues by calling first ahead of writing. 


\section{CONCLUSION}

The study was based on the supposition that with the increase in division and assessment of the tectonic, architectural design has more and more become a communicative organizational process, in which a variety of participants are concerned with different viewpoints and expertise. For that reason, the achievement of the project depends a lot upon how the team is organized and well thought of by having strategies that support facilitators and reduce inhibitors to communication.

Successful projects engage organizations that support frequent restructuring of their civilization and involve people in search of an advanced standard of success. The participant's obligation and devotion to the project's success also delivers an improved project. Consequently, the success of the project basically depends on the people and their organizations and the values determined in this thesis can assist the communications among these people and organizations.

\section{REFERENCES}

[1] Cheung, S.-O., Lam, T.-I., Leung, M.-Y., Wan, Y.-W. (2001). An analytical hierarchy process based procurement selection method. Construction Management and Economics 19 (4), 427-437.

[2] Ai Lin Teo, E., Ling, F.Y., Chong, A. (2005). Framework for project managers to manage construction safety. International Journal of Project Management 23 (4), 329-341.

[3] Dubois and Gadde (2002). The Construction Industry as a loosely coupled system. Implications for productivity and innovativity.

[4] Assaf, S.A., Al-Hejji, S. (2006). Causes of delay in large construction projects. International Journal of Project Management 24 (4), 349-357.

[5] (International Journal of Information Technology and Decision Making 2012)

[6] Fernie, S., Thorpe, A. (2007). Exploring change in construction: supply chain management. Engineering, Construction and Architectural Management 14 (4), 319-333.

[7] Dubois, A., \& Gadde, L. E. (2000). Supply strategy and network effects—purchasing behaviour in the construction industry. European journal of purchasing \& supply management, 6(3-4), 207-215.

[8] Green, S. (2002). The human resource management implications of lean construction: critical perspectives and conceptual chasms. Journal of Construction Research 3 (1), 147-165.

[9] Blyth, K., Lewis, J., Kaka, A. (2004)."Developing a framework for a standardized works programme for building projects", Construction Innovation, Vol. 4 No.4, pp.193.

[10] Brown et al. (2001). "The facilities management role in new building procurement", Facilities, Vol. 9 No.3/4, pp.119.

[11] World Bank (1996). World Bank Survey of International Construction Projects, World Bank, London,

[12] Zwikael, O., Shimizu, K., Globerson, S. (2005), "Cultural differences in project management processes: a field study", International Journal of Project Management, Vol. 23 No.6, pp.454-62.

[13] Kerzner, H. (2006). Project Management: A Systems Approach to Planning, Scheduling and Controlling, 9th ed., Wiley, New York, NY.

[14] Turner, J.R. (1999), The Handbook of Project-based Management: Improving the Processes for Achieving Strategic Objectives, McGraw-Hill, London.

[15] Lo, T.Y., Fung, I.W.H., Tung, K.C.F. (2006). Construction delays in Hong Kong civil engineering projects. Journal of Construction Engineering and Management 132 (6), 636-649. 
[16] Mansfield, N.R., Ugwu, O.O., Doran, T. (1994). Causes of delay and cost overruns in Nigerian construction projects. International Journal of Project Management 12 (4), 254-260.

[17] Kaming, P.F., Olomolaiye, P.O., Holt, G.D., Harris, F.C. (1997). Factors influencing construction time and cost overruns on high-rise projects in Indonesia. Construction Management and Economics 15 (1), 83-94.Frimpong et al. 2003

[18] Malik, M.A.K., McDermott, P., Swan, W. (2007). "Building trust in construction projects", Supply Chain Management, Vol. 12 No.6, pp.385-91.

[19] Meredith, J.R., Mantel, S.J. (2006), Project Management - A Managerial Approach, 6th ed., Wiley, New York, NY,

[20] Kerzner, H. (2006), Project Management: A Systems Approach to Planning, Scheduling and Controlling, 9th ed., Wiley, New York, NY,

[21] Zwikael, O., Shimizu, K., Globerson, S. (2005), "Cultural differences in project management processes: a field study", International Journal of Project Management, Vol. 23 No.6, pp.454-62.

[22] Russell, R.S., Taylor, B.W. (2003), Operations Management, 4th ed., Pearson Education, Upper Saddle River, NJ, .

[23] Chiu, Mao-Lin. (2002). An Organizational View of Design Communication in Design Collaboration Egan, J., 1998. Rethinking Construction. HMSO, London.

[24] Eriksson and Westerberg, (2010). Effects of cooperative procurement procedures on construction project performance: A conceptual framework. International Journal of Project Management 29 (2011) $197-208$

[25] Chan, A., Chan, A. (2004). Key performance indicators for measuring construction success. Benchmarking: An International Journal 11 (2), 203-221.

[26] Den Otter, A., \& Emmitt, S. (2007). Exploring effectiveness of team communication. Engineering, Construction and Architectural Management.

[27] Robinson, H.S., Carrillo, P.M., Anumba, C.J., Al-Ghassani, A.M. (2005), "Review and implementation of performance management models in construction engineering organisations", Construction Innovation, Vol. 5 No.4, pp.203-17.

[28] Rwamamara, R. (2007). Planning the Healthy Construction Workplace through Risk Assessment and Design Methods. Civil, Mining, and Environmental Engineering, Lulea ${ }^{\circ}$, Lulea ${ }^{\circ}$ University of Technology, Doctoral Thesis.

[29] Cooke-Davies, T. (2002). The "real" success factors on projects. International Journal of Project Management 20 (3), 185-190.

[30] Petersen, D.R., Murphree, E.L. (2004). The impact of owner representatives in a design-build construction environment, Project Management Journal, Vol. 35 No.3, pp.27-38.

[31] Munns, A.K., Bjeirmi, B.F. (1996). The role of project management in achieving project success. International Journal of Project Management 14 (2), 81-87.

[32] Leung, M.Y., Ng, S.T., Cheung, S.O. (2004). Measuring construction project participant satisfaction, Construction Management and Economics, Vol. 22 No.3, pp.319.

[33] Sarshar, M., Haigh, R., Amaratunga, D. (2004). Improving project processes: best practice case study, Construction Innovation, Vol. 4 No.2, pp.69-82. 
[34] The AIA handbook $14^{\text {th }}$ ed.pp.110

[35] Webster's 1984, Dictionary

[36] F Schneider, A Mágori, Z Orosz, T Pulay - Orvosi hetilap,( 2005). A review of the progress towards the adoption of supply chain management (SCM) relationships in construction. European Journal of Purchasing and Supply Management

[37] Septelka, D. M., \& Cooper, J. A. (2000). Construction of High Performance Equipment Foundations. In Construction Congress VI: Building Together for a Better Tomorrow in an Increasingly Complex World (pp. 768-777).

[38] Belle, R.A. (2002). Critical market forces and design-build, DBIA online.

\section{KAREN BOUJAOUDE KHOURY, Dr.}

She is worked as an Assistant Professor of Department of Architecture in Notre Dame University, Beirut, Lebanon since 2006. She also has worked as an Assistant Professor in Lebanese American University, Byblos, Lebanese in 2013-2014. She carries out planning and managing schedules for architectural projects since 2004. She holds a BSc. Degree in Architecture from Lebanese American University, a MSc. Degree in International Business from Bordeaux Business School, and a PhD degree in Business Administration from Grenoble Ecole de Management. Her research interests lie in architecture along with business management, communication, organization and problem diagnosis skills. 